\title{
Genotypic and phenotypic diversity of Bacillusspp. isolated from Freshwater Ecosystems
}

\author{
Mohanty S, Choudhury P. K, Dash A, Samanta M and Maiti N. $K^{*}$
}

A-Microbiology section, Division of Fish Health Management, Central Institute of Freshwater Aquaculture, Kausalyaganga, Bhubaneswar, Orissa, India, 751002

\begin{abstract}
The efficacy of the restriction fragment length polymorphism (RFLP) analysis of polymerase chain reaction (PCR) amplified rrs (16S ribosomal ribonucleic acid [rRNA] gene) for the identification of Bacillus spp. isolated from freshwater pond ecosystems was evaluated. Results showed that no restriction site differences occur between rrs operons within the bacteria belonging to the same species and as a result members of the same species yield very similar RFLP patterns at $100 \%$ similarity level. Cluster analysis of PCR-RFLP patterns grouped all the isolates into three clusters; each cluster represented a single species except one for which no placement was obtained. Phenotypic characteristics of the isolates were found to be well concordance with the results of PCR-RFLP. Our findings suggested that PCR- RFLP is suitable tool for discrimination and identification of endoglucanase positive Bacillus spp. isolated from freshwater ecosystems.
\end{abstract}

Keywords: Cellulolytic Bacillus spp.; 16SrDNA PCR- RFLP; 16SrDNA gene Sequencing

\section{Introduction}

Cellulose is a prominent carbonaceous constituent of plants and the most abundant organic compound in nature. In freshwater ecosystems it is a major constituent of aquatic plants [9] and major source of nutrients for other organisms [13]. The degradation of cellulose involves three enzymes $\beta$-glucosidase, endo- $\beta$-(1-4)-D-glucanase and exo- $\beta$ - (1-4)-D-glucanase, where these enzymes interact synergistically for the hydrolysis of cellulose [20]. The genus Bacillus is characterized by Gram-positive, aerobic or facultative anaerobic, rod-shaped bacteria that form spores, and contains more than 60 species that have quite different phenotypes and produces cellulase. These spore-forming bacteria represent a major microflora in many natural biotopes, where they play an important role in ecosystem development; they are able to transform many chemical compounds. DNA typing techniques using various methods for molecular characterization of Bacillus spp. have been developed, including the 16S-23S rDNA Intergenic Transcribed Spacer PCR (ITS-PCR) amplification [6,8], Restriction Fragment Length Polymorphisim of the ITS-PCR (ITS-PCR RFLP) for differentiation of species and strains [6], Randomly Amplified Polymorphic DNA (RAPD) [6] and Single Strand Conformation Polymorphisim (SSCP) [4] . The composition of benthic microbial communities can be readily studied by whole-cell fluorescence in situ hybridization [10]. Although FISH with fluorescently monolabeled oligonucleotide probes is an effective tool for studying microbial community structuring in various aquatic environments [2], its sensitivity is thought to depend on the growth state (i.e., ribosome content) of the target cells [1] .The objective of this study was to discriminate endoglucanase positive Bacillus spp. basedon16SrDNAPCR-RFLP.

\section{Materials and Methods \\ Isolation of cellulolytic bacillus spp}

Seventy sediment samples from carp rearing ponds were collected from uppermost layer at a depth of $4-5 \mathrm{~cm}$. The sizes of the rearing ponds were $0.1-0.4$ hectors. Alkalinity, $\mathrm{pH}$ and $\mathrm{DO}$ were $100-120 \mathrm{ppm}$, 7.5-8.0 and $4-5 \mathrm{mg} /$ lit respectively. The samples were pre-enriched in carboxymethyl cellulose (CMC) broth for 48 hrs. Screening was carried out, by spreading the serially diluted pre-enriched samples in CMC agar plates and well Separated colony was screened for cellulolytic activity by congo red binding assay [18]. All the strains were preserved in $40 \%$ glycerol at $-20^{\circ} \mathrm{C}$ for further use.

\section{Morphological, physiological, biochemical characterization}

The morphological characteristics of different isolates were studied by observing colony characters in CMC agar plates, Gram staining, endospore staining and subjected to further characterization by different biochemical tests. Physiological parameters included growth at different ranges of temperature $\left(25^{\circ} \mathrm{C}\right.$ to $\left.65^{\circ} \mathrm{C}\right)$ and sodium chloride concentration ( $2 \%$ to $10 \%)$.

\section{DNA extraction}

The isolates were grown in cellulose enrichment broth for overnight at $37^{\circ} \mathrm{C}$. Cultures $(10 \mathrm{ml})$ were pelleted by centrifugation at $5,000 \mathrm{rpm}$ for $10 \mathrm{~min}$ and DNA was extracted by the method as described [14]. DNA was precipitated by the addition of one volumes of isopropanol. The DNA was then dried and dissolved into 50 $\mu$ l TE buffer. DNA quality was checked by $0.8 \%$ agarose gel electrophoresis and quantified spectrophotometrically (6505 UV/VIS Spectrophotometer, Jenway).

\section{S rDNA amplification and restriction digestion}

The 16S rDNA gene from individual bacterial isolates was amplified by the polymerase chain reaction (PCR) with the $16 \mathrm{~S}$ primers [18]. The PCR reaction mixtures $(50 \mathrm{ml})$ contained, dNTPs each $2.5 \mathrm{mM} ; 10 \mathrm{X}$ PCR buffer $5 \mathrm{ml}$; each primer 20 pmol; Taq DNA polymerase (Genetix, India) $0.75 \mathrm{U}$ and bacterial DNA $100 \mathrm{ng}$. The forward primer was 5'AAG AGT TTG ATC CTG GCT CAG 3'and the reverse primer was 5' GGT

${ }^{*}$ Corresponding author: Dr. N. K. Maiti,,Principal Scientist, Microbiology section,,Division of Fish Health Management, Central Institute of Freshwate Aquaculture,Kausalyaganga, Bhubaneswar,Orissa, India, 751002, Tel. 91-6742465446;Fax: 91-674-2465407; E-mail: maitink@yahoo.co.in

Received December 14, 2010; Accepted January 20, 2011; Published May 11 2011

Citation: Mohanty S, Choudhury PK, Dash A, Samanta M, Maiti NK (2011) Genotypic and phenotypic diversity of Bacillus spp. isolated from Freshwate Ecosystems. J Aquac Res Development 2:112. doi:10.4172/2155-9546.1000112

Copyright: (c) 2011 Mohanty S, et al. This is an open-access article distributed under the terms of the Creative Commons Attribution License, which permits unrestricted use, distribution, and reproduction in any medium, provided the original author and source are credited. 
Citation: Mohanty S, Choudhury PK, Dash A, Samanta M, Maiti NK (2011) Genotypic and phenotypic diversity of Bacillus spp. isolated from Freshwater Ecosystems. J Aquac Res Development 2:112. doi:10.4172/2155-9546.1000112

TAC ATT GTT ACG ACT T 3'. The PCR was carried out in a thermal cycler (M. J. Research, Inc., Waltham, Massachusetts, USA) with initial denaturation of $94^{\circ} \mathrm{C}$ for 5 min followed by 35 cycles of denaturation at $94^{\circ} \mathrm{C}$ for $1 \mathrm{~min}$., annealing at $49^{\circ} \mathrm{C}$ for $2 \mathrm{~min}$., extension at $72^{\circ} \mathrm{C}$ for $2 \mathrm{~min}$ and a final extension at $72^{\circ} \mathrm{C}$ for $8 \mathrm{~min}$. Amplified DNA fragments were examined by horizontal electrophoresis in $2 \%$ agarose gel (Genei, India) containing ethidium bromide $(0.5 \mathrm{mg} / \mathrm{ml})$ at $100 \mathrm{~V}$ for $1 \mathrm{hr}$ in $1 \mathrm{X}$ TBE (Tris-Boric acid-EDTA) buffer with $5 \mathrm{ml}$ aliquots of PCR products. The gel images were digitized through UVP GelDocitTMimaging system, USA.

Three restriction endonucleases used in this study were Alu I, Hae III and Msp I (Genetix, India). PCR product (1 $\mu \mathrm{g})$ was digested with $1.5 \mathrm{U}$ of each enzyme at $37^{\circ} \mathrm{C}$ overnight. Digested PCR products were electrophoresed through $3 \%$ agarose gels containing $0.5 \mathrm{mg} / \mathrm{ml}$ ethidium bromide for approximately $2.5 \mathrm{hrs}$ at $100 \mathrm{~V}$ using $1 \mathrm{X} \mathrm{TBE}$ buffer and photographed in UVP GelDoc-itTMimaging system, USA.

\section{6s rDNA sequencing and identification}

PCR products of 17 different isolates from each composite genotype were purified by QIAquick PCR purification kit according to the manufacturer's instructions (QIAGEN, Germany). The purified PCR products were sequenced by Chromous Biotech, Chennai, India. A database search was performed using BLAST programme (NCBI, Maryland, USA) to identify the microorganisms at species level.

\section{Data analysis}

For cluster analysis, data were transformed to estimate distances [12] .The Unweighted Pair Group Method Using Arithmetic Averages (UPGMA) was used for cluster analysis for 16s PCR RFLP [16].

\section{Results and Discussion}

Forty one cellulolytic isolates from 70 pond sediment samples were obtained on the basis of CMC congo-red interaction assay, which showed halo zones, ranging from 14 to $44 \mathrm{~mm}$ diameter indicating quantitative variation in the enzyme production among the isolates. All the strains were found to be Gram positive, catalase and oxidase positive, spore-forming rods. Most of the strains utilized dextrose, $\mathrm{D}$-fructose, gelatin, casein, urea, mannose, trehalose, sucrose whereas, all the isolates were negative for indole production, L-rhamnose, D-melzitose phenylalanine deamination, hydrogen sulphide production. The isolates revealed variation in citrate utilization, amylase production, nitrate reduction, acetyl methyl carbinol production and sugar utilisation like; mannitol, sorbitol, L-arabinose, D-xylose.Twenty isolates showed amylase activity, 24 nitrate reduction activity, 19 phosphate solublization activity and 11 isolates lecithinase activity. The physiological studies showed the growth of 23 isolates at $60^{\circ} \mathrm{C}$ and only 8 isolates tolerate upto $10 \%$ salt concentration.

A specific product of $1.5 \mathrm{~kb}$ was obtained in $16 \mathrm{~S}$ rDNA PCR in all the isolates. PCR product digested with AluI(Figure 1A) showed one common band of molecular size 184bp, Hae III (Figure 1B) digestion produced three common bands of molecular size 435, 294 and 123bp and banding pattern obtained with MspI (Figure 1C) showed three common bands of 422, 220 and 132bp molecular size in all the isolates. Four different profiles were obtained with PCR products digested with AluI and three with both HaeIII and MspI. Patterns of each enzyme were combined together and each strain was assigned a composite genotype [19]. Based on this, 4 genotypes were obtained. In AluI digestion a common band of $265 \mathrm{bp}$ molecular size was found in all the isolates expect DCC genotype. Three bands of 632, 430, 242bp molecular size were exclusively present in DCC genotype. A unique band of $85 \mathrm{bp}$

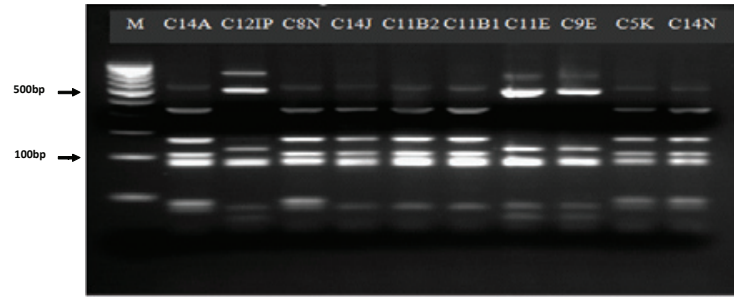

$A$
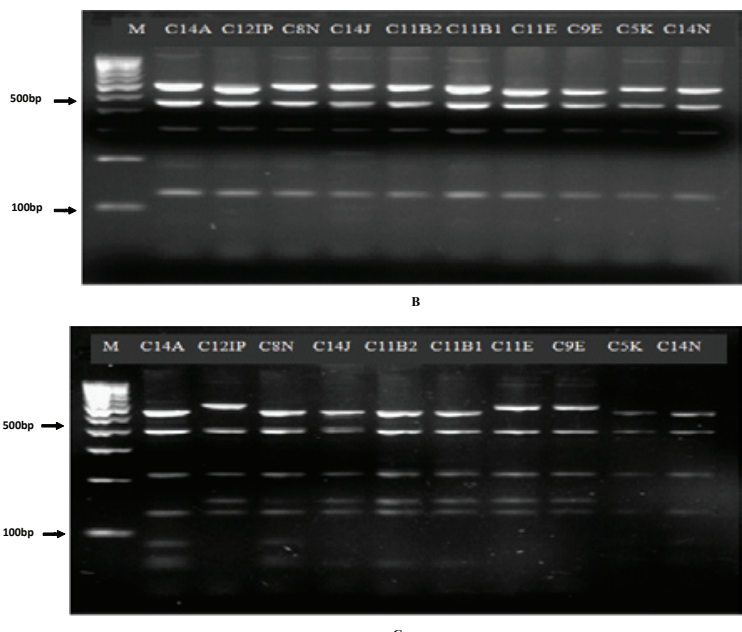

Figure 1: Agarose gel electrophoresis of $\operatorname{Alul}(\mathrm{A}), \mathrm{Hae} / I(\mathrm{~B}), \mathrm{Mspl}(\mathrm{C}) \mathrm{di}-$ gested PCR products of few representative samples . Lane M, size marker (100bp DNA ladder).

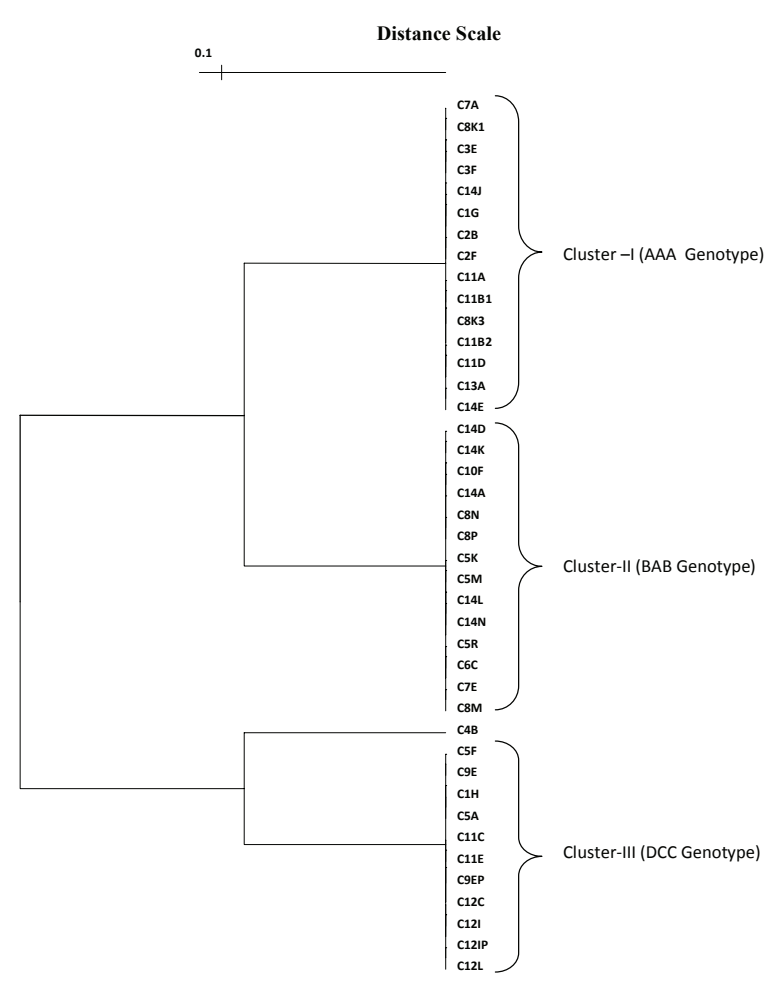

Figure 2: Dendrogram showing the genetic relationship of different isolates of cellulolytic Bacillus sp. constructed on the basis of $16 \mathrm{~S}$ rDNA PCR-RFLP pattern. 
Citation: Mohanty S, Choudhury PK, Dash A, Samanta M, Maiti NK (2011) Genotypic and phenotypic diversity of Bacillus spp. isolated from Freshwater Ecosystems. J Aquac Res Development 2:112. doi:10.4172/2155-9546.1000112

Page 3 of 4

\begin{tabular}{|c|c|c|c|c|c|c|c|c|}
\hline \multirow{2}{*}{$\begin{array}{l}\text { SAMPLE NUM- } \\
\text { BER }\end{array}$} & \multirow{2}{*}{$\begin{array}{l}\text { SPECIES } \\
\text { IDENTIFIED BY } \\
\text { PCR-RFLP }\end{array}$} & \multirow{2}{*}{ GENOTYPE } & \multirow{2}{*}{ CELLULASE } & \multirow{2}{*}{ AMYLASE } & \multirow{2}{*}{$\begin{array}{l}\text { PHOSPHATE } \\
\text { SOLUBILISA- } \\
\text { TION }\end{array}$} & \multirow{2}{*}{ LECITHINASE } & \multicolumn{2}{|c|}{ SALT TOLRANT } \\
\hline & & & & & & & $5 \%$ & $10 \%$ \\
\hline C7A & Bacillus subtilis & AAA & High & Positive & Positive & Negative & Positive & Positive \\
\hline C8K1 & Bacillus subtilis & AAA & High & Positive & Positive & Negative & Positive & Positive \\
\hline C3E & Bacillus subtilis & AAA & High & Positive & Positive & Negative & Positive & Positive \\
\hline C3F & Bacillus subtilis & AAA & High & Positive & Positive & Negative & Positive & Positive \\
\hline C14J & Bacillus subtilis & AAA & High & Positive & Positive & Negative & Positive & Positive \\
\hline C1G & Bacillus subtilis & AAA & High & Positive & Positive & Negative & Positive & Positive \\
\hline $\mathrm{C} 2 \mathrm{~B}$ & Bacillus subtilis & AAA & High & Positive & Positive & Negative & Positive & Positive \\
\hline $\mathrm{C} 2 \mathrm{~F}$ & Bacillus subtilis & AAA & High & Positive & Positive & Negative & Positive & Positive \\
\hline $\mathrm{C} 11 \mathrm{~A}$ & Bacillus subtilis & AAA & High & Positive & Positive & Negative & Positive & Positive \\
\hline C11B1 & Bacillus subtilis & AAA & High & Positive & Positive & Negative & Positive & Positive \\
\hline C11B2 & Bacillus subtilis & AAA & High & Positive & Positive & Negative & Positive & Positive \\
\hline C8K3 & Bacillus subtilis & AAA & High & Positive & Positive & Negative & Positive & Positive \\
\hline C11D & Bacillus subtilis & AAA & High & Positive & Positive & Negative & Positive & Positive \\
\hline C13A & Bacillus subtilis & AAA & High & Positive & Positive & Negative & Positive & Positive \\
\hline C14E & Bacillus subtilis & AAA & High & Positive & Positive & Negative & Positive & Positive \\
\hline
\end{tabular}

Table 1: Detailed characteristics of of the isolates grouped in cluster-I.

\begin{tabular}{|c|c|c|c|c|c|c|c|c|}
\hline \multirow{2}{*}{$\begin{array}{l}\text { SAMPLE NUM- } \\
\text { BER }\end{array}$} & \multirow{2}{*}{$\begin{array}{l}\text { SPECIES } \\
\text { IDENTIFIED BY } \\
\text { PCR-RFLP }\end{array}$} & \multirow{2}{*}{ GENOTYPE } & \multirow{2}{*}{ CELLULASE } & \multirow{2}{*}{ AMYLASE } & \multirow{2}{*}{$\begin{array}{l}\text { PHOSPHATE } \\
\text { SOLUBILISATION }\end{array}$} & \multirow{2}{*}{ LECITHINASE } & \multicolumn{2}{|c|}{ SALT TOLRANT } \\
\hline & & & & & & & $5 \%$ & $10 \%$ \\
\hline C14D & Bacillus pumilus & BAB & Medium & Negative & Negative & Negative & Positive & Positive \\
\hline C14K & Bacillus pumilus & BAB & Medium & Positive & Negative & Negative & Positive & Positive \\
\hline C10F & Bacillus pumilus & BAB & Medium & Negative & Negative & Negative & Positive & Positive \\
\hline C14A & Bacillus pumilus & BAB & Medium & Negative & Negative & Negative & Positive & Positive \\
\hline $\mathrm{C} 8 \mathrm{~N}$ & Bacillus pumilus & BAB & Medium & Negative & Negative & Negative & Positive & Positive \\
\hline C8P & Bacillus pumilus & BAB & Medium & Negative & Negative & Negative & Positive & Positive \\
\hline C5K & Bacillus pumilus & BAB & Medium & positive & Positive & Negative & Positive & Positive \\
\hline C5M & Bacillus pumilus & BAB & Medium & Negative & Negative & Negative & Positive & Positive \\
\hline C14N & Bacillus pumilus & BAB & Medium & Negative & Positive & Negative & Positive & Positive \\
\hline C5R & Bacillus pumilus & BAB & Medium & Negative & Negative & Negative & Positive & Positive \\
\hline $\mathrm{C} 6 \mathrm{C}$ & Bacillus pumilus & BAB & Medium & Negative & Positive & Negative & Positive & Positive \\
\hline C7E & Bacillus pumilus & BAB & Medium & Negative & Negative & Negative & Positive & Positive \\
\hline C8M & Bacillus pumilus & BAB & Medium & Negative & Positive & Negative & Positive & Positive \\
\hline C14L & Bacillus pumilus & BAB & Medium & Negative & Negative & Negative & Positive & Positive \\
\hline
\end{tabular}

Table 2: Genotypic and phenotypic characteristics of the isolates in cluster-II.

\begin{tabular}{|c|c|c|c|c|c|c|c|c|}
\hline \multirow{2}{*}{$\begin{array}{l}\text { SAMPLE NUM- } \\
\text { BER }\end{array}$} & \multirow{2}{*}{$\begin{array}{l}\text { SPECIES } \\
\text { IDENTIFIED BY } \\
\text { PCR-RFLP }\end{array}$} & \multirow[b]{2}{*}{ GENOTYPE } & \multirow[b]{2}{*}{ CELLULASE } & \multirow[b]{2}{*}{ AMYLASE } & \multirow{2}{*}{$\begin{array}{l}\text { PHOSPHATE } \\
\text { SOLUBILISA- } \\
\text { TION }\end{array}$} & \multirow[b]{2}{*}{ LECITHINASE } & \multicolumn{2}{|c|}{ SALT TOLRANT } \\
\hline & & & & & & & $5 \%$ & $10 \%$ \\
\hline C5F & Bacillus cereus & DCC & Low & Negative & Negative & Positive & Positive & Negative \\
\hline C9E & Bacillus cereus & DCC & Low & Negative & Negative & Positive & Positive & Negative \\
\hline $\mathrm{C} 1 \mathrm{H}$ & Bacillus cereus & DCC & Low & Negative & Negative & Positive & Positive & Negative \\
\hline C5A & Bacillus cereus & DCC & Low & Negative & Negative & Positive & Positive & Negative \\
\hline C11C & Bacillus cereus & DCC & Low & Negative & Negative & Positive & Positive & Negative \\
\hline C11E & Bacillus cereus & DCC & Low & Negative & Negative & Positive & Positive & Negative \\
\hline C9EP & Bacillus cereus & DCC & Low & Negative & Negative & Positive & Positive & Negative \\
\hline C12C & Bacillus cereus & DCC & Low & Negative & Negative & Positive & Positive & Negative \\
\hline $\mathrm{C} 12 \mathrm{I}$ & Bacillus cereus & DCC & Low & Negative & Negative & Positive & Positive & Negative \\
\hline C121P & Bacillus cereus & DCC & Low & Negative & Negative & Positive & Positive & Negative \\
\hline C12L & Bacillus cereus & DCC & Low & Negative & Negative & Positive & Positive & Negative \\
\hline
\end{tabular}

Table 3: Detailed characteristics of of the isolates grouped in cluster-I.

molecular size was present only in BAB genotypes. In HaeIII restriction digestion pattern there was no difference in the banding pattern between AAA and BAB genotypes, where as DCC genotype could be differentiated from other two groups by a specific band of 565bp molecular size. In MspI restriction digestion a band of $154 \mathrm{bp}$ molecular size was absent in $\mathrm{BAB}$ genotype. In AAA genotype and DCC genotype all bands were same except a band of $581 \mathrm{bp}$ which were present in AAA genotype. 16S rDNAs of 17 isolates, eight from AAA genotype, seven from DCC genotype and two from BAB genotype were sequenced. A database search was performed using BLAST programme (NCBI, Maryland, USA) to identify the microorganisms at species level. All the isolates from AAA, BAB and DCC genotypes were identified as Bacillus subtilis, Bacillus pumilus and Bacillus cereus respectively. The alignment showed 99-98\% sequence similarity. Heyndrickx et al. [7] observed the 
Citation: Mohanty S, Choudhury PK, Dash A, Samanta M, Maiti NK (2011) Genotypic and phenotypic diversity of Bacillus spp. isolated from Freshwater Ecosystems. J Aquac Res Development 2:112. doi:10.4172/2155-9546.1000112

frequent occurrence of interoperon variability of the 16S rRNA gene in Bacillus and Paenibacillus. Because PCR-RFLP detects interspecies and interstrain as well as interoperon variability and enables a relatively fast multiple strain analysis per taxon. This PCR-RFLP fingerprinting allows the construction of a database for identification purposes. Shangkuan et al. [15] reported that PCR-RFLP is simple to perform and has potential as a rapid method for typing and discriminating $B$. anthracis strains from other $B$. cereus group bacteria.. On the contrary, PCR-RFLP fingerprinting failed to identify Brevibacillus agri and Brevibacillus brevis [11]. Dendrogram (Figure 2) constructed from 16s rDNA PCR-RFLP data showed three different clusters. Cluster-I comprised of all AAA genotypes, cluster-II BAB genotype and clusterIII DCC genotypes. In between cluster-I and cluster-II similarity of $\leq$ $90 \%$ was observed where as cluster-III was distantly related to both cluster-I and cluster-II. However isolate C4B couldnot be clustered.

Analysis of phenotypic/functional characteristics of these clusters revealed that cellulase production in terms of zone size was highest in Bacillus subtilis, intermediate in Bacillus pumilus and lowest in Bacillus cereus. (Tables1,2,3) All the isolates of cluster-I two of cluster-II were positive for starch degradation (amylase production), and the property was absent in all the isolates of cluster-III. Phosphate solubilization was absent in all the isolates of cluster-III where as all the isolates of cluster-I and four isolates of cluster-II were positive for phosphate solubilization. Lecithinase activity was exclusively present in all isolates of cluster-III. Salt resistance of the isolates was less in cluster-III (5\%) where as it was comparatively high $(10 \%)$ in other two clusters. It indicates that genetic relatedness of three species of bacillus coincided well with the phenotypic relationship of the species.

The identification of microbial species by phenotypic methods can sometimes be uncertain, complicated and time-consuming. The use of molecular methods has revolutionised their identification, by improving the quality and effectiveness of this identification. Some of these methodologies use either the rDNA spacer region or its target. These techniques are useful for the identification and reliable detection of different bacterial species as well as the monitoring of the species [3]. Our approach using 16S rRNA gene has enabled comprehensive characterization of cellulolytic Bacillus spp. predominating in freshwater ecosystems. This study shows that PCR-RFLP as an alternative to more laborious techniques used for endoglucanase positive Bacillus spp. identification and characterization, such as the morphological and physiological analyses or the determination of the 16S rRNA gene sequence, can be used as an identification tool. The results were validated by $16 \mathrm{~S}$ rDNA sequencing of isolates selected at random from each cluster.

\section{Acknowledgements}

Financial support received from Indian Council of Agricultural research, New Delhi, India for carrying out this work is acknowledged.

\section{References}

1. Amann R, Ludwig W (2000) Ribosomal RNA-targeted nucleic acid probes for studies in microbial ecology. FEMS Microbiol Rev 24:555-565.

2. Amann R, Ludwig W, Schleifer KH (1995) Phylogenetic identification and in situ detection of individual microbial cells without cultivation. Microbiol Rev 59 143-169.

3. Blaiotta G, Fusco V, Ercolini D, Aponte M, Pepe O, et al. (2008) Lactobacillus strain diversity based on partial $h s p 60$ gene sequences and design of PCRrestriction fragment length polymorphism assays for species identification and differentiation. Appl Environ Microbiol 74: 208-215.

4. Borin S,Daffionchio D, Sorlini C (1997) Single strand confirmation polymorphism of PCR-tDNA fingerprinting to address the identification of Bacillus species. FEMS Microbiol Lett 157: 87-93.
5. Daffonchio D , Borin S, Consolandi A, Mora D, Manachini PL,et al. (1998) 16S-23S rRNA internal transcribed spacers as molecular markers for the species of the 16S rRNA group I of the genus Bacillus. FEMS Microbiol Lett 163: 229-236.

6. Gurtler V, Stanisich V A (1996) New approaches to typing and identification of bacteria using the 16S-23S rDNA spacer region .Microbiology 142: 3-16.

7. Heyndrickx M V, Auterin L,Vandamme P, Kersters K, De Vos P (1996) Applicability of combined amplifed 16S rDNArestriction analysis (ARDRA) patterns in bacterial phylogeny and taxonomy.JMicrobiol Methods 26: 247-259.

8. Johnson YA, Nagpal MM, Krahmer TK, Fox A (2000) Precise molecular weigh determination of PCR products of the rRNAintergenic spacerregion using electrospray quadrupole mass spectrometry for differentiation of B.subtilis and $B$. atrophaeus, closely related species of bacilli. J Microbiol Methods 40: 241 254

9. Lindsay GHJ, Hariss JE (1980) Carboxymethylcellulose activity in the digestive tract of fish. J Fish Biol 16: 219-233

10. Llobet-Brossa E, Rossello-Mora R, Amann R (1998) Microbial community composition of Wadden Sea sediments as revealed by fluorescence in situ hybridization. Appl Environ Microbiol 64: 2691-2696.

11. Logan NA, Forsyth GL, Lebbe J, Goris M , Heyndrickx A, et al.(2002) Polyphasic identification of Bacillus and Brevibacillus strains from clinical, dairy and industrial specimens and proposal of Brevibacillusinvocatus spp Nov Int Sys Evol Microbiol 52:953-966.

12. Nei M, Li WH (1979) Mathematical model for studying genetic variation in terms of restriction endonucleases. Proc Natl Acad Sci USA 76: 5269-5273.

13. Saha AK ,Ray AK(1998) Cellulase activity in rohu fingerlings. Aqua Int 6: 281 291

14. Schmalenberger A, Schwieger F, Tebbe CC (2001) Effects of primers hybridizing to different evolutionarily conserved regions of the small-subunit rRNA gene in PCR-based microbial community analyses and gene profiling control. App Environ Microbiol 67: 3557-3563.

15. Shangkuan YH, Yang JF, Lin HC, Shaio MF (2000) Comparison of PCRRFLP, ribotyping and ERIC-PCR for typing Bacillus anthracis and Bacillus cereus strains. J ApplMicrobiol 89: 452-462.

16. Sokal RR, Michener CD (1958) A statistical method for systematic relationships. Univ Kans Sci Bull 38: 1409-1438.

17. Stanley J Baquar N, Burnens A (1995) Molecular subtyping scheme for Salmonella panama. J ClinMicrobiol 33: 1206-1211.

18. Teather RM, Wood PJ (1982) Use of congo red-polysaccharidesinteractions in enumeration and characterization of cellulolytic bacteria from the bovine rumen. Appl EnvironMicrobiol 43: 777-780.

19. Urakawa H, Kita-Tsukamoto K, Ohwada K (1999) 16 S rDNA restriction fragmen length poltmorphism analysis of psychrotrophic Vibrios from Japanese coastal water. Can J Microbiol 45: 1001-1007.

20. Zhang YHP, Lynd LR (2004) Towards an aggregated understanding of enzymatic hydrolysis of cellulose: non complexed cellulase systems. Biotechno Bioeng 88: 797-824. 